Endocrinol. Japon. 1988, 35 (1), 39-45

\title{
Effect of Parathyroid Function on Serum Bone Gla Protein
}

\author{
Masahiro YONEDA, Kensuke TAKATSUKI, Kazuyuki YAMAUCHI, \\ Yutaka OISO, Masaei KUROKAWA, AKitoshi KAWAKUBO, \\ *YUji TORIMOTO, **Hiroomi FUNAHASHI AND ***AKIo TOMITA
}

\author{
First Department of Internal Medicine, *First and **Second Department of \\ Surgery, Nagoya University School of Medicine, Tsurumai-cho, \\ Showa-ku, Nagoya, 466 Japan \\ ***Central Laboratory for Clinical Investigation, Aichi Medical University \\ Nagakute-cho, Aichi-gun, Aichi-ken, 480-11 Japan
}

\begin{abstract}
The serum bone Gla protein (BGP) level was measured in patients with idiopathic hypoparathyroidism, and primary hyperparathyroidism, and normal volunteers. The mean serum BGP level was $4.5 \pm 0.20 \mu \mathrm{g} / \mathrm{l}$ in 40 normal volunteers. It was significantly lower in 12 patients with idiopathic hypoparathyroidism $(1.6 \pm 0.21 \mu \mathrm{g} / 1, \mathrm{p}<0.001)$ and significantly higher in 33 patients with primary hyperparathyroidism $(13.0 \pm 1.3 \mu \mathrm{g} / 1, \mathrm{p}<0.001)$.

When a single intravenous injection of $30 \mu \mathrm{g}$ of human PTH 1-34 was administered to the patients with idiopathic hypoparathyroidism, there was no significant change in serum BGP within the next 24 hours. Following a therapeutic oral dose of alfacalcidol, serum BGP was appreciably increased $(\mathrm{p}<0.001)$ from the preadministration value of $1.6 \pm 0.21 \mu \mathrm{g} / 1$ to $3.9 \pm 0.34 \mu \mathrm{g} / 1$.

In patients with primary hyperparathyroidism, the surgical excision of parathyroid adenoma led to a sharp decrease in serum PTH but a gradual decrease in serum BGP. The latter approximately paralleled the decline in serum alkaline phosphatase.

Thus, serum BGP is a marker that reflects bone turnover status in parathyroid disease. It appears that the active form of vitamin $\mathrm{D}$ directly increases the secretion of BGP in existing osteoblasts and PTH mainly affects serum BGP to stimulate the bone remodeling cycles with its long term effect.
\end{abstract}

Serum bone $\gamma$-carboxyglutamic acid (Gla)-containing protein (BGP) is thought to be a sensitive and specific marker of bone turnover (Price et al., 1980). The serum BGP level has been investigated in various disease of bone metabolism. BGP is increased in primary hyperparathyroidism

Received May 15, 1987

Correspondence to: Tsurumai-cho, Showa-ku, Nagoya, 466, Japan
(Price et al., 1980; Delmas et al., 1983; Yoneda et al., 1986a) and decreased in idiopathic hypoparathyroidism (Delmas et al., 1983). In addition, the serum BGP concentration has been closely correlated with bone formation but not bone resorption (Price et al., 1981; Delmas et al., 1986).

It has been demonstrated that active vitamin $\mathrm{D}$ acts on osteoblasts, accelerating BGP synthesis and secretion (Price and 
Baukol, 1980; Spiess et al., 1986) and elevating its concentration in serum (Key et al., 1984). On the other hand PTH inhibits BGP production of human bone cells (Beresford et al., 1984).

Our group has reported that, in patients with primary hyperparathyroidism, the serum BGP concentration is a marker which, together with the urinary Gla concentration, reflects abnormalities in bone metabolism (Yoneda et al., 1986a), and further, that synthetic salmon calcitonin, which possesses the capacity to inhibit bone resorption, reduces the amount of serum BGP (Yoneda et al., 1986b).

In the present investigation, we first compared the serum BGP concentration in patients with primary hyperparathyroidism and idiopathic hypoparathyroidism.

We next investigated the effect of synthetic PTH 1-34 and alfacalcidol on the serum BGP concentration in patients with idiopathic hypoparathyroidism. We then studied the relationship between the serum BGP concentration and the various factors which regulate calcium metabolism in patients with primary hyperparathyroidism. Finally, to determine the effect of parathyroid adenoma excision on serum BGP, we monitored the acute effect on biochemical parameters for 24 hours following surgery and up to one year postoperatively. From these data, we attempted to elucidate the effect of PTH and vitamin D on serum BGP in patients with parathyroid disease.

\section{Materials and Methods}

The subjects studied were 33 patients with primary hyperparathyroidism (30 cases of parathyroid adenoma and 3 cases of parathyroid hyperplasia), 12 patients with idiopathic hypoparathyroidism, and 40 normal controls. None showed reduced renal function. The sex ratio and age distribution were similar in the 3 groups.

For baseline determinations blood samples were collected from patients with primary hy- perparathyroidism and idiopathic hypoparathyroidism before therapy in the early morning and fasting.

The following studies were carried out to investigate the effects of PTH and vitamin D on serum BGP in the patients with idiopathic hypoparathyroidism in whom endogenous PTH plays no part.

PTH loading test (Ellsworth-Howard Test) : Four patients with idiopathic hypoparathyroidism received $30 \mu \mathrm{g}$ of synthetic human PTH 1-34 (Toyo Jozo Co., Ltd.; Shizuoka, Japan) administered by intravenous infusion over a period of 5 minutes. The concentration of BGP was measured in blood collected before hormone administration and again at $15 \mathrm{~min}, 30 \mathrm{~min}$, one $\mathrm{h}, 2 \mathrm{~h}, 6 \mathrm{~h}, 12 \mathrm{~h}$ and $24 \mathrm{~h}$ afterwards.

Effect of vitamin $\mathrm{D}$ administration: To normalize the serum $\mathrm{Ca}$ concentration, each patient with idiopathic hypoparathyroidism received alfacalcidol orally in a dose of $2-3 \mu \mathrm{g} / \mathrm{day}$ for a year. The serum BGP concentration was determined during therapy.

Next, to investigate the effect of surgical removal of the parathyroid adenoma on the serum BGP concentration, serum BGP was monitored in 14 patients with primary hyperparathyroidism for one year following the procedure. Data were analyzed to detect any correlation of the various serum biochemical factors with the BGP concentration.

After collection, blood samples were centrifuged in a refrigerated centrifuge to obtain the serum, which was stored in a $-20^{\circ} \mathrm{C}$ freezer until measured.

PTH was measured by a previously described radioimmunoassay method (Yoneda et al., 1983) using an antibody specific for human PTH 46-84 (C-terminal assay). In this immunoassay the upper limit of normal was $0.5 \mu \mathrm{g} / 1$.

The serum concentrations vitamin D metabolites were measured by the improved multiple assay procedure (Kimura et al., 1982); 25-OHD by competitive protein binding assay; $1,25(\mathrm{OH})_{2}$ D by radioreceptor assay, and $24,25(\mathrm{OH})_{2} \mathrm{D}$ by competitive protein binding assay. The mean serum concentrations of $25-\mathrm{OHD}, 1,25(\mathrm{OH})_{2} \mathrm{D}$ and $24,25(\mathrm{OH})_{2} \mathrm{D}$ obtained in 46 normal adults were $23.5 \pm 1.0 \mu \mathrm{g} / 1, \quad 32.4 \pm 0.6 \mathrm{ng} / 1$ and $0.81 \pm$ $0.05 \mu \mathrm{g} / 1$, respectively.

BGP was measured with a radioimmunoassay kit (Immuno Nuclear Co., Stillwater, Minnesota). The antibody used in this kit was obtained by 
immunizing rabbits with bovine BGP (Gundberg et al., 1985).

Serum Ca, albumin and alkaline phosphatase were determined with an autoanalyzer (Technicon SMAC Jr.). The normal range was 2.1 to 2.5 $\mathrm{mmol} / 1$ for $\mathrm{Ca}, 3.7$ to $5.0 \mathrm{~g} / \mathrm{dl}$ for albumin and 30 to $115 \mathrm{IU} / 1$ for alkaline phosphatase. The serum Ca was corrected for serum albumin (Payne et al., 1973).

Data are reported as the mean $\pm \mathrm{SE}$. They were assessed by Student's $t$-test and the paired $t$-test for significant differences.

\section{Results}

The mean serum BGP concentration in the normal controls was $4.5 \pm 0.20 \mu \mathrm{g} / 1$. It was significantly lower in the patients with idiopathic hypoparathyroidism $(1.6 \pm 0.21$ $\mu \mathrm{g} / 1, \mathrm{p}<0.001)$ and significantly higher in the patients with primary hyperparathyroi$\operatorname{dism}(13.0 \pm 1.3 \mu \mathrm{g} / 1, \mathrm{p}<0.001)$ (Fig. 1).

In the patients with idiopathic hypoparathyroidism, the serum BGP concentration showed no significant change during the first 24 hours after PTH administration (Fig. 2).

In contrast, a therapeutic dose of alfacalcidol given orally produced a statistically significant $(\mathrm{p}<0.001)$ increase in serum BGP: from the preadministration value of $1.6 \pm 0.21 \mu \mathrm{g} / 1$ to $3.9 \pm 0.34 \mu \mathrm{g} / 1$ postadministration (Fig. 3).

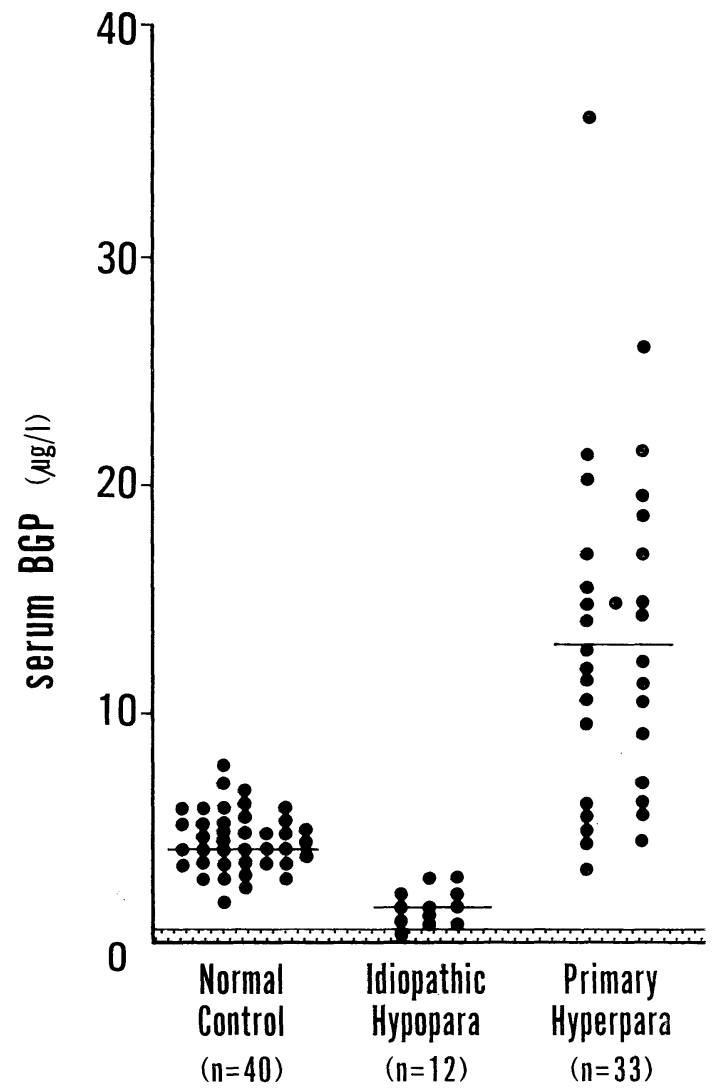

Fig. 1. Serum BGP concentration in 12 patients with idiopathic hypoparathyroidism, in 33 patients with primary hyperparathyroidism and 40 normal controls. The concentration mean is indicated for control and disease groups, respectively. The shaded area represents the undetectable range.

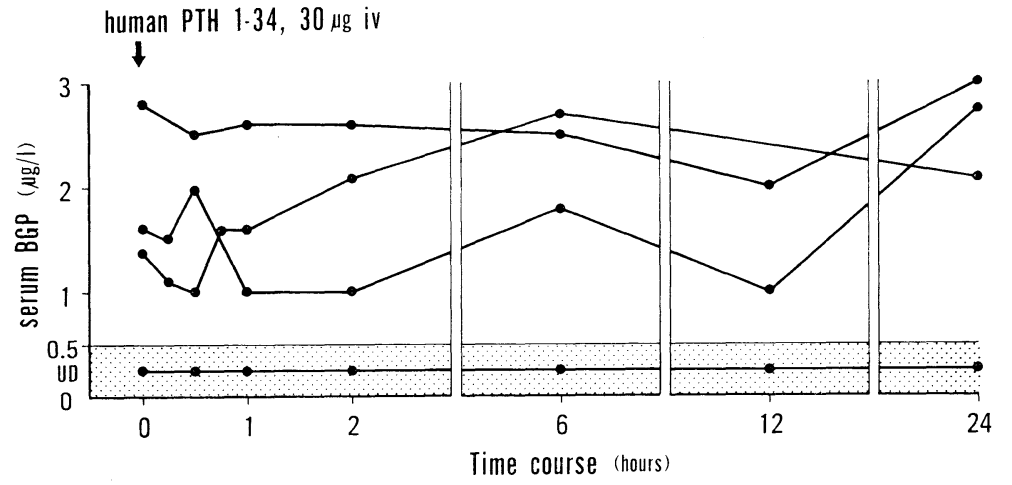

Fig. 2. Effect of single dose human PTH 1-34 administration on serum BGP in 4 patients with idiopathic hypoparathyroidism. Shaded area represents the undetectable range. 


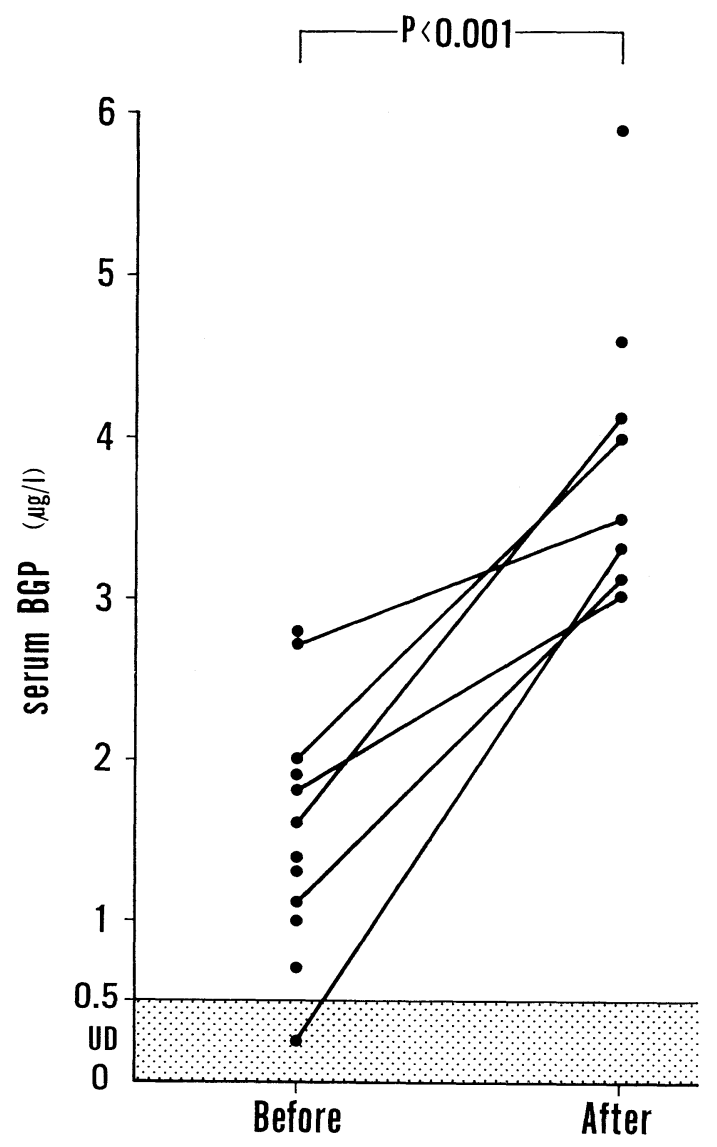

Fig. 3. Serum BGP concentration before and after alfacalcidol treatment $(2-3 \mu \mathrm{g}$, daily) in patients with idiopathic hypoparathyroidism. Shaded area represents the undetectable range. $\mathbf{P}<0.001$ vs the preadministration value.

Table 1. Correlation between serum BGP and other factors in patients with primary hyperparathyroidism.

\begin{tabular}{|c|c|c|c|c|c|}
\hline & & PTH & 25OHD & $\begin{array}{c}1,25 \\
(\mathrm{OH})_{2} \mathrm{D}\end{array}$ & $\begin{array}{c}24,25 \\
(\mathrm{OH})_{2} \mathrm{D}\end{array}$ \\
\hline & $\mathrm{n}$ & 33 & 19 & 19 & 19 \\
\hline BGP & $\mathrm{r}$ & 0.42 & -0.40 & 0.28 & -0.23 \\
\hline vs & $\mathrm{p}$ & $<0.02$ & NS & NS & NS \\
\hline
\end{tabular}

As shown in Table 1, serum BGP in patients with primary hyperparathyroidism showed a positive correlation with serum PTH $(r=0.42, p<0.02)$. There was no significant correlation between $\mathrm{BGP}$ and serum concentrations of 25-OHD, $1,25(\mathrm{OH})_{2}$ $\mathrm{D}$ or $24,25(\mathrm{OH})_{2} \mathrm{D}$.

The excision of the parathyroid adenoma led to a sharp decrease in serum PTH (Fig. 4). However, there was no significant change in serum BGP during the 24 hour period following surgery, and BGP decreased very gradually (Fig. 5). In 7 such patients, we monitored serum $\mathrm{Ca}, \mathrm{PTH}$, alkaline phosphatase and BGP for one year after the surgery. Those data are plotted in Fig. 6. $\mathrm{Ca}$ and PTH in serum decreased rapidly after surgery and at six months the serum alkaline phosphatase concentration showed a significant $(\mathrm{p}<0.005)$ decrease from the presurgical value of $220 \pm 36 \mathrm{IU} / 1$ to $130 \pm 26 \mathrm{IU} / 1$.

At three months the serum BGP concentration had decreased significantly $(\mathrm{p}<$ 0.05 ) from the presurgical value of $15.7 \pm$ $2.3 \mu \mathrm{g} / 1$ to $9.0 \pm 1.5 \mu \mathrm{g} / 1$. There was a significant positive correlation $(\mathrm{r}=0.76, \mathrm{p}<$ 0.01 ) between the serum BGP and alkaline phosphatase values during the year following the surgery.

\section{Discussion}

As has been reported by other groups (Price et al., 1980; Delmas et al., 1983) who studied serum BGP in parathyroid disease, we demonstrated that the serum concentration of BGP is significantly decreased in idiopathic hypoparathyroidism and significantly increased in primary hyperparathyroidism as compared to normal controls. Clearly, parathyroid function strongly influences serum BGP.

Dose this mean that PTH directly influences the serum BGP concentration?

In patients with primary hyperparathy- 

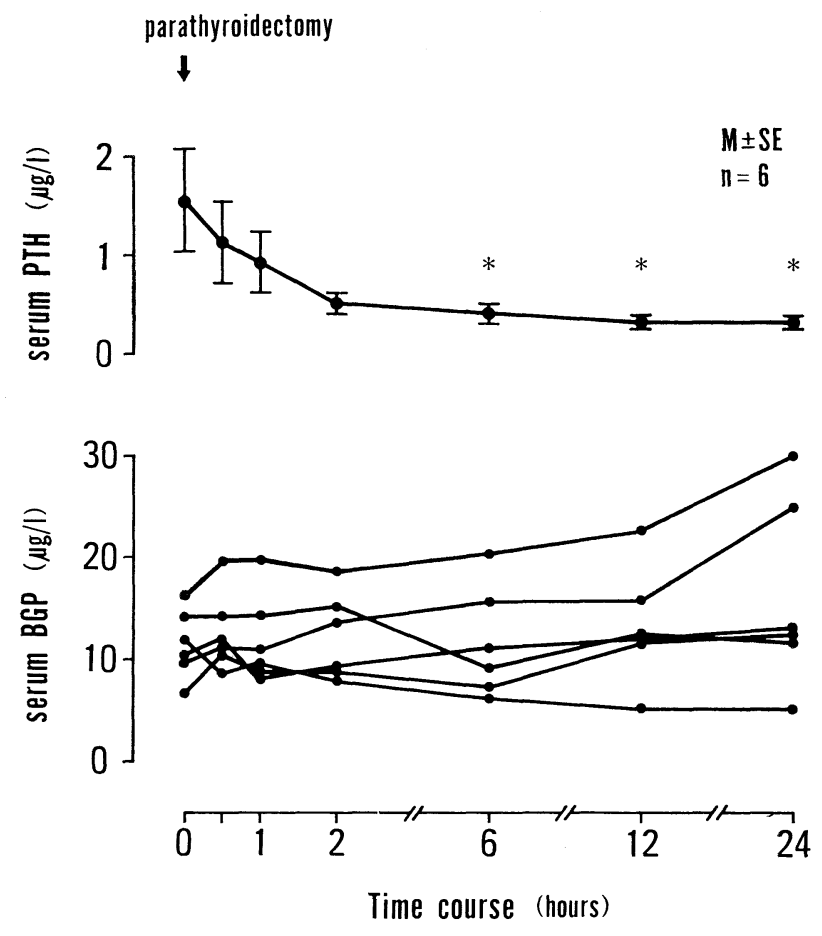

Fig. 4. Changes in serum PTH and BGP concentration during 24 hours after parathyroidectomy in 6 patients with primary hyperparathyroidism. $* \mathbf{P}<$ 0.05 vs before operation value.

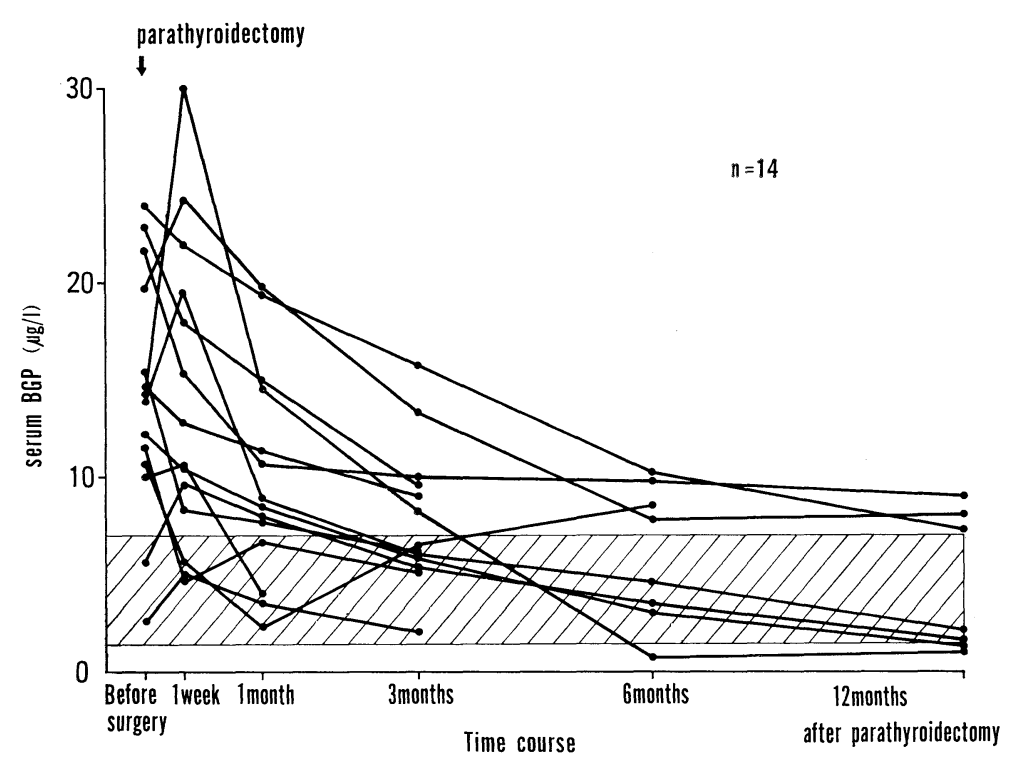

Fig. 5. Individual serum BGP values before and after parathyroidectomy in 14 patients with primary hyperparathyroidism. Shaded area represents the normal control value $( \pm 2 S D)$. 

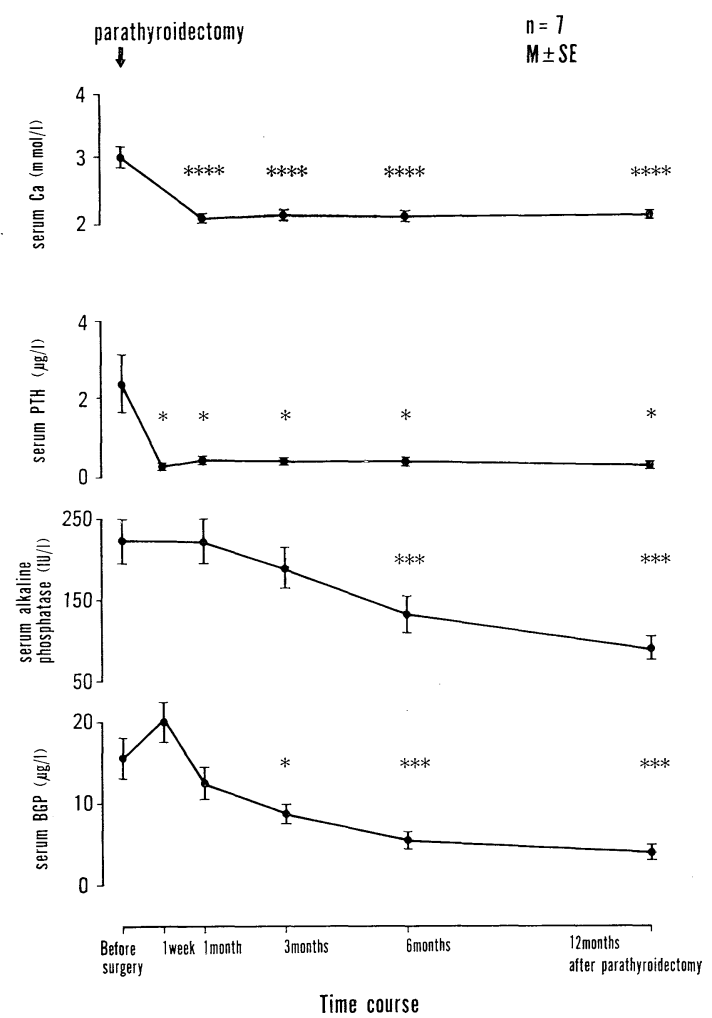

Fig. 6. Changes in serum $\mathrm{Ca}$, PTH, alkaline phosphatase and BGP concentration after parathyroidectomy in 7 patients with primary hyperparathyroidism. $* \mathbf{P}<0.05, \quad * * \mathbf{P}<0.01$, $* * * \mathrm{P}<0.005,{ }^{* * * *} \mathrm{P}<0.001$ vs before operation values.

roidism, the serum BGP concentration was positively correlated with that of serum PTH. This correlation was statistically significant. But PTH inhibits BGP production of human osteoblasts (Beresford et al., 1984) and when the parathyroid adenoma was excised, no significant change in serum BGP was detected when one would have expected an immediate and striking decrease and when bone resorption should show a marked improvement. This finding makes it difficult to believe that PTH acts directly on serum BGP. Moreover, the increase in serum BGP seen in primary hyperparathyroidism is not believed to result from the release from the bone matrix due to the accompanying accelerated resorption of bone, but rather from the accelerated secretion of BGP by osteoblasts. In addition, if one considers that, following the surgical removal of the parathyroid adenoma, changes in serum BGP and the alkaline phosphatase concentration show a close correlation, credence is lent to the concept that the serum BGP concentration is a specific marker of bone turnover (Price et al, 1981; Delmas et al., 1986).

Furthermore, in patients with idiopathic hypoparathyroidism, the intravenous administration of at least $30 \mu \mathrm{g}$ of PTH had no effect on serum BGP within the subsequent 24 hours. From this and other findings, we infer that PTH does not act acutely on existing osteoblasts to bring about an accelerated synthesis and secretion of BGP. Rather, it seems that the long term effect of PTH alters the rate of formation of remodeling cycles and affects the serum BGP concentration by bringing about an increase in the number of osteoblasts in bone and stimulating their activity, and by also accelerating the activation of vitamin $\mathrm{D}$ in the kidney.

In parayhyroid disease, is the serum BGP concentration perhaps controlled by the serum vitamin $\mathrm{D}$ concentration?

That the active form of vitamin $\mathrm{D}$ accelerates the synthesis and secretion of BGP by osteoblasts has been demonstrated in vitro (Price and Baukol, 1980; Skj $\phi \mathrm{dt}$ et al., 1985). In studies conducted in vitro, active vitamin $\mathrm{D}$ increased the serum BGP concentration in patients with osteopetrosis (Key et al., 1984). In our study as well, treatment of patients with idiopathic hypoparathyroidism with oral alfacalcidol led to an increase in the serum BGP concentration. It can be concluded that active vitamin $\mathrm{D}$ is capable of acting directly to increase the serum BGP concentration without the participation of PTH. However, in primary hyperparathyroidism, the concentration of BGP had no correlation with 
any of the three vitamin $\mathrm{D}$ metabolites: 25-OHD, $1,25(\mathrm{OH})_{2}$ D or $24,25(\mathrm{OH})_{2}$ D.

Thus it is seen that active vitamin D has a direct effect on the increase in the secretion of BGP in existing osteoblasts. But it seems that PTH has a stronger effect, which stimulates the bone remodeling cycle, than vitamin $\mathrm{D}$ in patients with primary hyperparathyroidism.

On the basis of our findings, we conclude that, in parathyroid diseases, the serum BGP concentration is a marker which reflects the status of bone metabolic turnover, especially of bone formation, and that active vitamin D directly increases the secretion of BGP in existing osteoblasts and PTH mainly affects the serum BGP level to increase the number of osteoblasts in bone remodeling cycles with its long term effect.

\section{References}

Beresford, J. N., J. A. Gallagher, J. W. Poser and R. G. G. Russell (1984). Production of osteocalcin by human bone cells in vitro. Effects of $1,25(\mathrm{OH})_{2} \mathrm{D}_{3}, \quad 24,25(\mathrm{OH})_{2} \mathrm{D}_{3}$, parathyroid hormone and glucocorticoids. Metab. Bone Dis. and Rel. Res. 5, 229-234.

Delmas, P. D., H. W. Wahner, K. G. Mann and B. L. Riggs (1983). Assessment of bone turnover in postmenopausal osteoporosis by measurement of serum bone Gla-protein. $J$. Lab. Clin. Med. 102, 470-476.

Delmas, P. D., B. Demiaux, L. Malaval, M. C. Chapuy, C. Edouard and P. J. Munier (1986). Serum bone gamma carboxyglutamic acidcontaining protein in primary hyperparathyroidism an in malignant hypercalcemia. J. Clin. Invest. 77, 985-991.

Gundberg, C. M., P. S. Wilson, P. M. Gallop and A. M. Parfitt (1985). Determination of osteocalcin in human serum: Results with two kits compared with those by a well-charactered assay. Clin. Chem. 31, 1720-1723.

Key, L., D. Carnes, S. Cole, M. Holtrop, Z. Bar-Shavit, F. Shapiro, R. Arceci, J. Steinberg, C. Gundberg, A. Kahn, S. Teilbaum and C. Anast (1984). Treatment of congenital osteo- petrosis with high-dose calcitriol. N. Engl. J. Med. 310, 409-415.

Kimura, Y., Y. Ogura, M. Nanjo and Y. Nishii (1982). An improved multiple assay procedure for vitamin $\mathrm{D}$ and its metabolites. J. J. B. M. 15, 49-57. (In Japanese).

Payne, R. B., A. J. Little, R. B. Williams and J. R. Milner (1973). Interpretation of serum calcium in patients with abnormal serum proteins. Br. Med. J. 4, 643-646.

Price, P. A., J. G. Parthmore and L. J. Deftos (1980). New biochemical marker for bone metabolism. J. Clin. Invest. 66, 878-883.

Price, P. A. and S. A. Baukol (1980). 1,25dihydroxyvitamin D increases synthesis of the vitamin K-dependent bone protein by osteosarcoma cells. J. Biol. Chem. 255, 1166011663.

Price, P. A., M. K. Williamson and J. W. Lothringer (1981). Origin of the vitamin Kdependent bone protein found in plasma and its clearance by kidney and bone. J. Biol. Chem. 256, 12760-12766.

Skj $\phi d t$, H., J. A. Gallagher, J. N. Beresford, M. Couch, J. W. Poser and R. G. G. Russell (1985). Vitamin D metabolites regulate osteocalcin synthesis and proliferation of human bone cells in vitro. J. Endocr. 105, 391-396.

Spiess, Y. H., P. A. Price, J. L. Deftos and S. C. Manolagas (1986). Phenotype-associated changes in the effects of 1,25-dihydroxyvitamin $\mathrm{D}_{3}$ on alkaline phosphatase and bone Glaprotein of rat osteoblastic cells. Endocrinology 118, 1340-1346.

Yoneda, M., A. Tomita, T. Uchikawa and K. Takatsuki (1983). Basic and clinical studies on human parathyroid hormone using the homologous radioimmunoassay kit "Eiken". Horumon to Rinsho 31, 379-383 (In Japanese).

Yoneda, M., K. Takatsuki, Y. Oiso, T. Takano, M. Kurokawa, A. Ota, A. Tomita, T. Ohno, K. Okano and T. Kanazawa (1986a). Clinical significance of serum bone Gla protein and urinary Gla as biochemical markers in primary hyperparathyroidism. Endocrinol. Japon. 33, 89-94.

Yoneda, M., K. Takatsuki, A. Kawakubo, M. Kurokawa, T. Takano, S. Kawakita $\mathbf{S}$ and A. Tomita (1986b). Effect of salmon calcitonin on serum bone Gla protein in primary hyperparathyroidism. J. Bone Mineral Metab. 4, 83-88. 